Revue bibliographique pour le domaine irano-aryen

\title{
Annalisa Azzoni, Elspeth R. M. Dusinberre. «Persepolis Fortification Aramaic Tablet Seal 0002 and the Keeping of Horses "
}

\section{Astrid Nunn}

\author{
(2) OpenEdition \\ Journals \\ Édition électronique \\ URL : http://journals.openedition.org/abstractairanica/42556 \\ DOI : 10.4000/abstractairanica.42556 \\ ISBN : 1961-960X \\ ISSN : 1961-960X \\ Éditeur : \\ CNRS (UMR 7528 Mondes iraniens et indiens), Éditions de l'IFRI
}

\section{Référence électronique}

Astrid Nunn, «Annalisa Azzoni, Elspeth R. M. Dusinberre. «Persepolis Fortification Aramaic Tablet Seal 0002 and the Keeping of Horses » », Abstracta Iranica [En ligne], Volume 37-38-39 | 2018, document 2, mis en ligne le 10 mars 2018, consulté le 27 septembre 2020. URL : http://

journals.openedition.org/abstractairanica/42556; DOI : https://doi.org/10.4000/abstractairanica. 42556

Ce document a été généré automatiquement le 27 septembre 2020.

Tous droits réservés 


\title{
Annalisa Azzoni, Elspeth R. M. Dusinberre. « Persepolis Fortification Aramaic Tablet Seal 0002 and the Keeping of Horses »
}

\author{
Astrid Nunn
}

\section{RÉFÉRENCE}

Annalisa Azzoni, Elspeth R. M. Dusinberre, « Persepolis Fortification Aramaic Tablet Seal 0002 and the Keeping of Horses ", in Michael Kozuh, Wouter F. M. Henkelman, Charles E. Jones, Christopher Woods (eds.). Extraction \& Control: Studies in Honor of Matthew W. Stolper. Studies in Ancient Oriental Civilization 68. Chicago, The Oriental Institute of the University of Chicago, 2014, p. 1-16.

1 Des milliers de tablettes des fortifications de Persépolis environ 700 ont été écrites en araméen. Les A. en ont choisi une car l'assemblage du texte et du sceau leur parait particulièrement intéressant. Le texte liste des noms de personnes liées à la distribution de grain aux chevaux et partiellement connues d'autres textes araméens. Le sceau - un maître des animaux - apparait lui aussi sur d'autres tablettes, aussi bien araméennes qu'élamites, et exemplifie ainsi le réseau multiculturel de l'administration persépolitaine. 


\section{AUTEURS}

\section{ASTRID NUNN}

Université de Munich 